\title{
DNA-Templated [2+2] Photocycloaddition: A Straightforward Entry into the Aplysinopsin Family of Natural Products**
}

\author{
Nicolas Duchemin, ${ }^{+}$Adam Skiredj, ${ }^{+}$Justine Mansot, Karine Leblanc, Jean-Jacques Vasseur, Mehdi A. \\ Beniddir, Laurent Evanno, * Erwan Poupon, * Michael Smietana, ${ }^{*}$ and Stellios Arseniyadis*
}

\begin{abstract}
Biosynthetic considerations inspired us to harness the template properties offered by DNA to promote a [2+2] photo-induced cycloaddition. The method was developed based on the dimerization of (E)-aplysinopsin, which was previously shown to be unproductive in solution. In sharp contrast, exposure of this tryptophan-derived olefin to light in the presence of salmon testes DNA (st-DNA) reproducibly afforded the corresponding homo-dimerized spiro-fused cyclobutane in excellent yields. DNA provides unique templating interactions enabling a singular mimic of the solid-state aggregation necessary for the [2+2] photo-cycloaddition to occur. This method was ultimately used to promote the prerequisite dimerizations leading to both dictazole $B$ and tubastrindole $B$, thus constituting the first example of a DNA-mediated transformation to be applied to the total synthesis of a natural product.
\end{abstract}

The importance of light-induced reactions in biosynthetic transformations is undisputable as showcased by the thousands of examples found in nature. ${ }^{[1]}$ Interestingly however, despite the significant efforts made in the field, ${ }^{[2]}$ photochemical reactions still remain underused in natural product synthesis mainly due to the difficulty in taming the high-energy intermediates involved during the process. Exploiting supramolecular interactions and confinement to modify the excited-state behaviour of molecules has emerged as a particularly appealing strategy. ${ }^{[3]}$ The use of cucurbituril, fullerenes and, more recently, cyclodextrins, just to name a few, has allowed a preorganization of the reactants and ultimately a control of the photochemical process. ${ }^{[4]}$

Since Roelfes' and Feringa's seminal paper published a bit over a decade ago, ${ }^{[5]}$ the field of DNA-based asymmetric catalysis has been thriving resulting in the development of a number of catalytic transformations by several groups ${ }^{[6]}$ including ours. ${ }^{[7]}$ The field

[*] N. Duchemin, Dr. S. Arseniyadis

Queen Mary University of London

School of Biological and Chemical Sciences

Mile End Road, London, E1 4NS (UK)

E-mail: s.arseniyadis@qmul.ac.uk

A. Skiredj, K. Leblanc, Dr. M. A. Beniddir, Dr. L. Evanno, Prof. Dr. E. Poupon

Laboratoire de Pharmacognosie associé au CNRS

UMR 8076 BioCIS, Université Paris-Sud

5 rue Jean-Baptiste Clément

92296 Châtenay-Malabry (France)

E-mail: erwan.poupon@u-psud.fr

E-mail: laurent.evanno@u-psud.fr

J. Mansot, Dr. J.-J. Vasseur, Prof. Dr. Michael Smietana Institut des Biomolécules Max Mousseron, UMR 5247 Université de Montpellier, ENSCM

Place Eugène Bataillon, 34095 Montpellier (France)

E-mail: michael.smietana@umontpellier.fr

$+\quad$ These authors contributed equally

[**] Supporting information for this article is available on the WWW recently culminated with the development of a [2+2] photocatalysed cycloaddition ${ }^{[8]}$ involving a modified three-way junction DNA bearing a covalently-attached photo-sensitizer. This elegant approach prompted us to explore yet another interesting feature offered by DNA, namely its template properties, to promote a photodimerization process perhaps otherwise impossible. As a model reaction, we decided to study the photo-induced cycloaddition of (E)-aplysinopsin monomers in solution. Indeed, in our quest to validate the biosynthetic hypotheses of various structurally intriguing cyclobutane-containing natural products, we recently showed that the $(E)$-aplysinopsin monomers could undergo a [2+2] photo-cycloaddition to produce the dictazole-type spiro-fused cyclobutanes, however this reaction was only possible under solvent-free conditions (Figure 1A). ${ }^{[9]}$ In comparison, the reactions performed in solution failed to provide any of the desired product. To circumvent this lack of reactivity in solution, we envisioned a DNA-templated strategy ${ }^{[10]}$ where the compartmentalization properties offered by DNA could allow to bypass the inability of the monomers to self-organize in solution and ultimately promote the title cycloaddition. Most importantly, if successful, this strategy could be extended to the synthesis of a number of cyclobutanecontaining natural products and analogues thereof (Figure 1B).

Our first set of experiments rapidly revealed that DMF $(3.75 \mathrm{v} / \mathrm{v} \%)$ was necessary to solubilize $(E)$-aplysinopsin 1a $(1.5 \mathrm{mM})$ in the aqueous buffer solution (MOPS, $20 \mathrm{mM}, \mathrm{pH} 6.5$ ) containing st-DNA ( $3 \mathrm{mM} \mathrm{bp}$ ). In a typical reaction, the mixture was stirred by inversion in quartz tubes under a UV-B enriched lamp (ReptiSun 10.0 ZOOMED ${ }^{\circledR}$ UV-B) for 4 days and the product distribution was determined by HPLC-UV-MS analysis (Table 1). Interestingly, under these initial conditions, we were able to observe the formation of the desired dimerized product $\mathbf{2 a}$ (Table 1, entry 2), while a control experiment run in the absence of DNA (Table 1, entry 3) only produced the formylindole derivative thus demonstrating the crucial role played by DNA in this reaction. It is also worth pointing out that increasing the percentage of DMF or the concentration of the substrate had a detrimental effect on the conversion of 1a to $\mathbf{2 a}$ (Table 1, entries 4-5). With these preliminary results in hand, we next evaluated the photophysical features offered by the complexing properties of a series of water-compatible Lewis acids (not shown in Table 1, see ESI for details). Interestingly, the use of $\mathrm{La}(\mathrm{OTf})_{3}$ appeared to improve the yield to up to $56 \%$. However, similar yields could also be obtained by simply improving the solubility of the starting material by adding a DNA-compatible co-solvent such as $\mathrm{DMSO}^{[11]}(25 \mathrm{v} / \mathrm{v} \%)$ instead of the Lewis acid (Table 1, entries 6-8).

The head-to-tail dimerization resulting from the topochemical control of the DNA-templated photodimerization was also confirmed by ${ }^{1} \mathrm{H}$ and ${ }^{13} \mathrm{C}$ NMR analysis after running the reaction on a 0.15 mmol preparative scale. ${ }^{[12]}$ Interestingly, the homodimerized product $2 \mathrm{a}$ was obtained in up to $65 \%$ yield $(40 \%$ isolated yield after preparative HPLC) after running the reaction for $48 \mathrm{~h}$ (Scheme 1A). ${ }^{[13]}$ The latter was accompanied with $11 \%$ of $\mathbf{2 a}$, ( $8 \%$ isolated yield) bearing the dictazole A-type syn stereochemistry 
A. Aplysinopsins family: dictazoles as synthetic gateways

- Aplysinopsins

$>20$ known substances
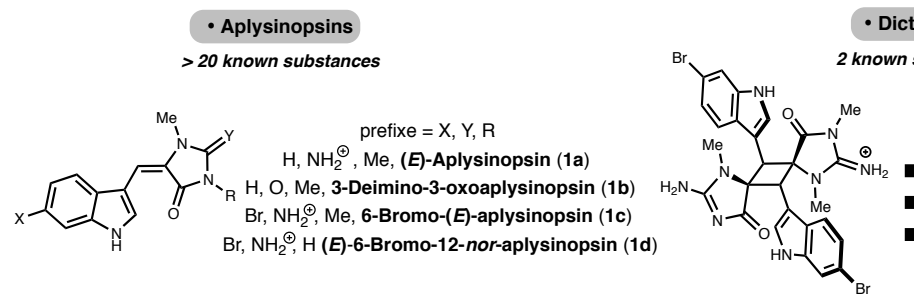

Dictazole B (2d)

- Cyclobutane-centered marine alkaloid

- Central platform in the "aplysinopsins' cascade"

- Unknown biosynthesis

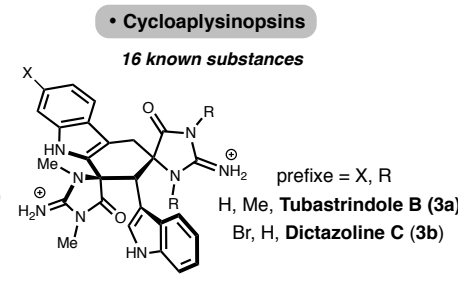

- B. This work: DNA-templated total synthesis of dictazoles, biomimetic entry into the "aplysinospins' cascade

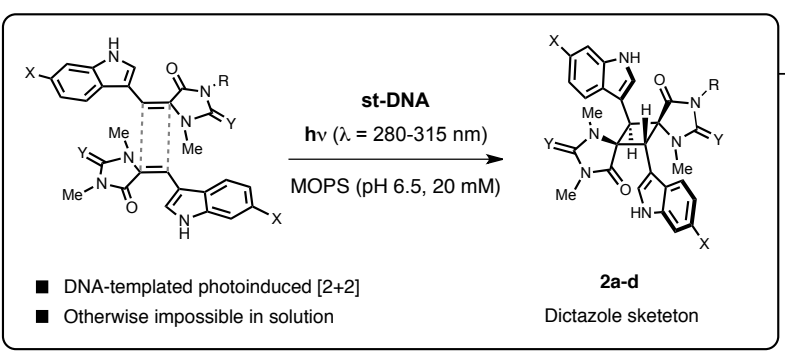

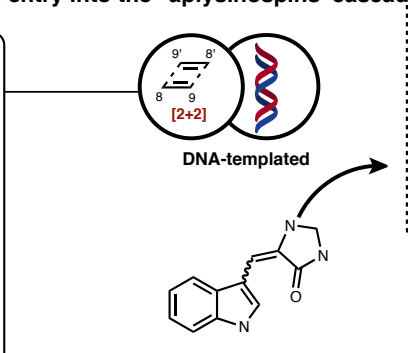

Aplysinopsins

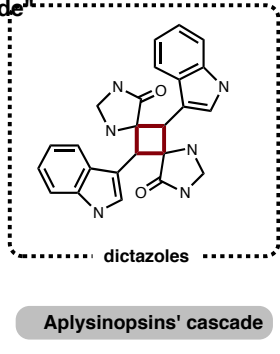

Aplysinopsins' cascade

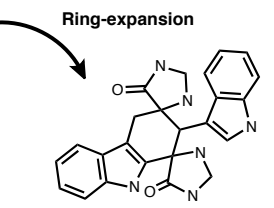

Cycloaplysinopsins

Figure 1. DNA-templated photoinduced [2+2] cycloaddition of aplysinopsins

resulting from the dimerization of $(E)$-aplysinopsin with its $(Z)$ isomer formed in situ. Hence, the optimized DNA-based photodimerization conditions led to an unprecedented $76 \%$ combined yield, affording $20 \mathrm{mg}$ of the spiro-fused cyclobutane in a single batch. In contrast, the solid-state protocol required combining 14 batches, each on a $0.025 \mathrm{mmol}$ scale, to isolate roughly the same amount of product ( $40 \%$ conversion, $14 \%$ isolated yield).

In order to rationalize the intricate interaction between the aplysinopsin analogues and DNA, we performed circular dichroism (CD) experiments. Indeed, non-covalent ligands that bind to DNA via intercalation, groove binding or sometimes external binding, display characteristic CD signals. ${ }^{[14]}$ In addition, while single binding modes are rarely observed with neutral ligands, the presence of cationic charges further increases the number of possible modes of interaction. As shown in Figure 2A, st-DNA exhibits a typical B-type CD spectrum characterized by a negative and a positive Cotton effect at $\lambda=245$ and $278 \mathrm{~nm}$ respectively. Upon addition of compound 1a into a solution containing st-DNA $(30 \mu \mathrm{M})$, no CD activity could be observed when $\mathrm{R}<1 \quad(\mathrm{R}=[\mathbf{1} \mathrm{a}] /[\mathrm{DNA}])$. Interestingly, when the concentration of $\mathbf{1 a}$ was increased from $\mathrm{R}=1$ to $\mathrm{R}=2$ while keeping the concentration of st-DNA constant, a new biphasic CD signal with a strong positive $(340 \mathrm{~nm})$ and a broad negative $(390 \mathrm{~nm})$ maximum and a zero cross-over at $360 \mathrm{~nm}$ was observed (Figure 2A). The appearance of this bisignate shape was concomitant with a small decrease of intensity of st-DNA bands attributed to a small change in the winding of the nucleobase pairs around the DNA helix. The splitting of the ICD signal into a positive and a negative band is characteristic of an exciton coupling effect which arises when two or more dissymmetrically arranged chromophores interact with each other through space. It is generally taken as evidence for the formation of dimers or higher order complexes and characteristic of groove binding or external stacking. ${ }^{[15-17]}$ Obviously, as compound 1a is an achiral molecule, the presence of a CD signal in solution is characteristic of a chiral organisation. More specifically, the presence of exciton-coupled bisignate bands strongly supports groove binding, ligand-ligand binding or electrostatic interactions. ${ }^{[18]}$ Interestingly, upon increasing the ionic strength of the buffer from 0 to $1 \mathrm{M} \mathrm{NaCl}$, new CD spectral features were observed (Figure 2B). While the st-DNA bands in the 200-300 region were not affected, the original excitoncoupled CD signals observed at lower ionic strength entirely disappeared and were replaced by a broad negative band at $\lambda=400 \mathrm{~nm}$. This suggests that at low ionic strength, electrostatic and groove binding modes majorly contribute to the CD spectra, while at higher ionic strength, phosphodiesters are totally paired with sodium cation and therefore groove binding predominates. ${ }^{[19]}$

The DNA-templated formation of helical stacked aggregates of cationic organic molecules is a well-studied phenomenon. ${ }^{[20,21]}$ It has notably been shown that electronic couplings occurs in $\mathrm{H}$-aggregates (parallel stacking) and J-aggregates (head-to-tail stacking). By analogy with well-studied cationic groove binders such as distamycin, we thus hypothesized that two aplysinopsin molecules could stack head-to-tail with charged groups positioned at opposite ends. ${ }^{[22,23]}$ This spatial arrangement would allow the photoinduced $[2+2]$ cycloaddition to occur.

To corroborate the importance of these multiple interaction modes, two control experiments were performed. First, to probe the importance of the groove binding interactions, we attempted to form a 2:1 complex between 1a and the biologically relevant pyrophosphate (PPi) to mimic DNA's phosphate backbone. ${ }^{[2]}$ In that case, irradiation of the mixture failed to provide the desired cycloaddition product thus confirming not only that an electrostatically-induced sandwich-like dimer cannot homodimerize but also that the groove binding aggregation is necessary. Second, to evaluate the influence of the electrostratic interactions, we set up the

\section{Table 1. Systematic study}

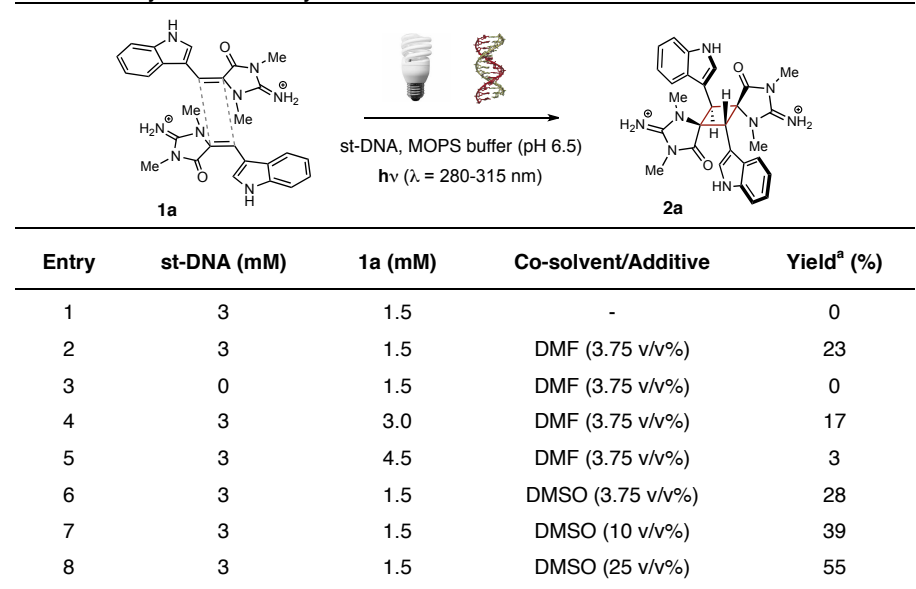

Conditions: All reactions were ran in $2 \mathrm{~mL}$ quartz tubes: a $6 \mathrm{mM}$ base pair solution of st-DNA in $20 \mathrm{mM}$ MOPS ( $500 \mu \mathrm{L}, \mathrm{pH}$ 6.5) was slowly added to a $3 \mathrm{mM}$ solution of $(E)$-aplysinopsin 1a in a 1:1 MOPS $(20 \mathrm{mM}, \mathrm{pH} 6.5) / \mathrm{DMSO}$ solution $(500 \mu \mathrm{L})$ at $\mathrm{rt}$ under artificial light during $96 \mathrm{~h}$. ${ }^{a}$ All yields were determined by HPLC analysis (reproducibility $\pm 3 \%$; average over three independent runs). 


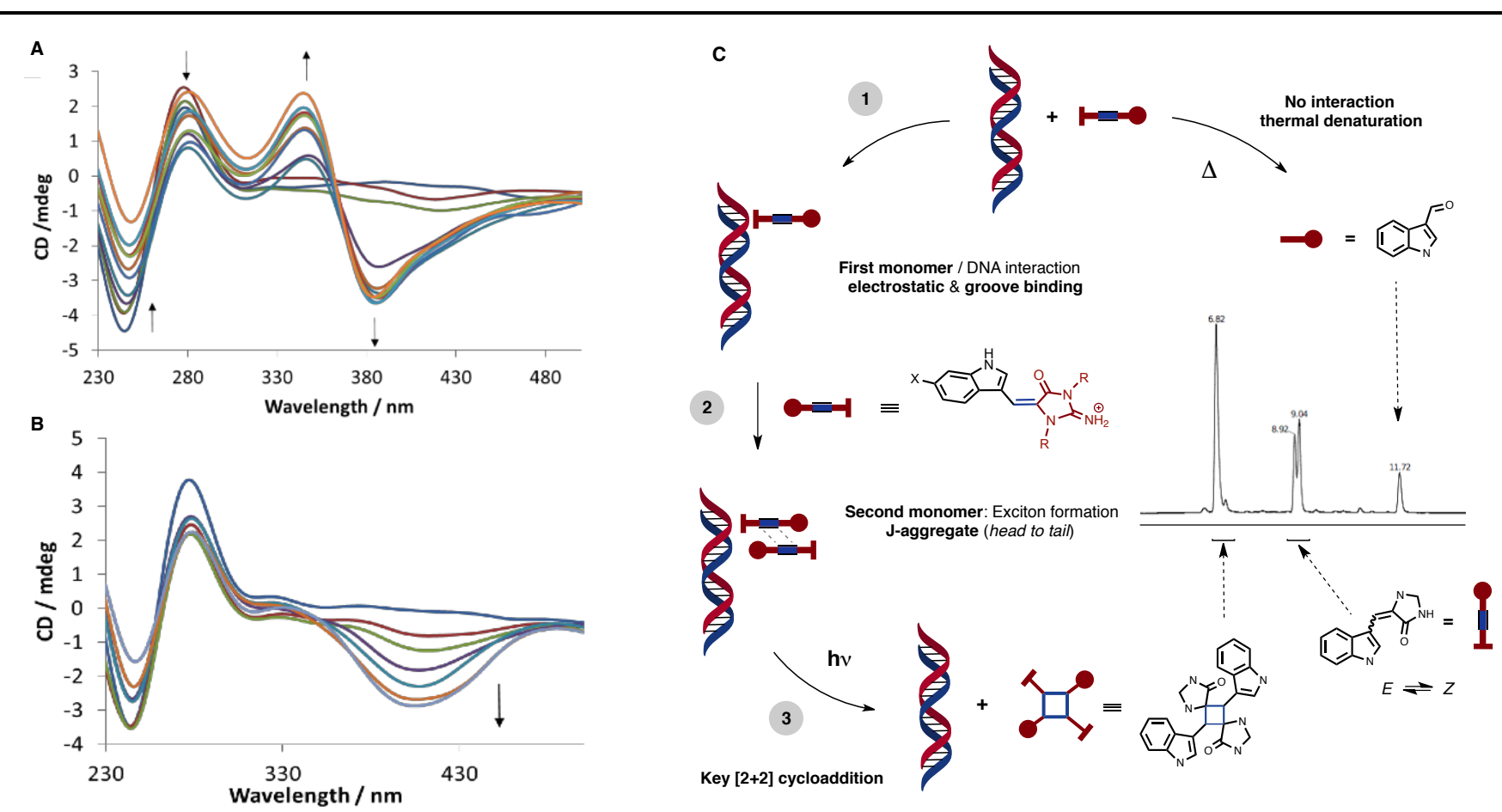

Figure 2. (A) CD spectra changes of st-DNA $(30 \mu \mathrm{M})$ in MOPS buffer $(20 \mathrm{mM}, \mathrm{pH} 6.5,0 \mathrm{M} \mathrm{NaCl})$ at $5^{\circ} \mathrm{C}$ upon addition of compound $\mathbf{1 a}(0-70 \mu \mathrm{M})$, (B) $\mathrm{CD}$ spectra changes of st-DNA $(30 \mu \mathrm{M})$ in MOPS buffer $(20 \mathrm{mM}, \mathrm{pH} 6.5,1 \mathrm{M} \mathrm{NaCl})$ at $5{ }^{\circ} \mathrm{C}$ upon addition of compound 1a $(0-60 \mu \mathrm{M})$. (C) Rationalization of the DNA-templated [2+2] cycloaddition and representative HPLC chromatogram.

homophotodimerization of the 3'-deimino-3'-oxoaplysinopsin $\mathbf{1 b}$ bearing a neutral urea moiety instead of the guanidium present in 1a (Scheme 1, B). Here again, no pseudodictazole resulting from the $[2+2]$ cycloaddition was observed thus supporting the importance of the electrostatic binding between the aplysinopsin monomers and the polyanionic backbone of DNA.

Based on these results, we propose a plausible cascade of events (Figure 2C) featuring: 1 the electrostatic and groove binding of a first leading monomer, 2 the aggregation and groove binding of a second monomer in a head-to-tail conformation to avoid charge repulsion and 3 the key [2+2] cycloaddition. This pathway should therefore not only allow the homodimerization of a positively charged monomer, but also a potential heterodimerization with a second monomer which would aggegrate in the DNA groove. If confirmed, this would allow a straightforward entry into the natural hetero-dimer dictazole B (2d).

To support this scenario, we logically started by evaluating the dimerization of the brominated analogue 1c on a preparative scale. Interestingly, the use of a $3 \mathrm{mM}$ base pair concentration of st-DNA in $25 \mathrm{v} / \mathrm{v} \%$ DMSO at room temperature afforded the expected pseudo-dictazole $2 \mathrm{c}$ albeit in only $14 \%$ isolated yield (Scheme 1, C). In this case, the reaction mainly led to the recovery of the starting monomer and only traces of the brominated formyl indole. This lower yield compared to the one obtained for the homodimerization of 1a can be explained by the fast disassembly of the resulting cyclobutane product 2c within a few hours in solution, as experimentally observed on a pure sample.

We then naturally sought to apply our optimized conditions to a 1:1 mixture of 1c and 1d hoping to favour the formation of the natural heterodimer, dictazole B (Scheme 1, D). Indeed, this structurally fascinating framework featuring a four-membered ring spirocyclic scaffold and isolated form the sponge Smenospongia cerebriformis, ${ }^{[25]}$ belongs to the aplysinopsin family of indole marine natural products which also includes aplysinopsin (1a) and its deimino and brominated analogues $\mathbf{1 b}, \mathbf{1 c}$ and 1d, (Figure 1B), ${ }^{[26]}$ and the tetrahydrocarbazole cycloaplysinopsins; tubastrindole B (3a) and dictazoline $\mathrm{C}(\mathbf{3 b}) \cdot{ }^{[25,27-30]}$ We recently suggested a potential biosynthetic scenario for these natural products featuring a unified "aplysinopsin cascade", where the dictazoles are the central dimers en route to the cycloaplysinopsins. ${ }^{[31]}$ While this hypothesis still remains questionable as far as biosynthetic considerations are concerned, this DNA-templated approach allows a straightforward and particularly efficient entry into this family of natural products.

To our delight, the condensation of the two monomers $1 \mathbf{c}$ and $\mathbf{1 d}$ led to the formation of the corresponding heterodimer, which spectral data matched those reported in the literature for natural dictazole B (2d). ${ }^{[9]}$ Even more surprising was the efficacy of the reaction, as the natural product was obtained in an improved $16 \%$ isolated yield in a single run $(0.15 \mathrm{mmol}$ scale $),{ }^{[32]}$ which compared favourably with the $3.4 \%$ previously obtained after combining 28 batches, each on a $0.025 \mathrm{mmol}$ scale. This could potentially be explained by the postulated competitive disassembly of $\mathbf{2 c}$ in solution during the course of the reaction, which would favour the predominant formation of the more stable heterodimer 2d. Finally, the enantioselectivity obtained for dictazole B, although modest ( $7 \%$ ee), further confirmed the implication of DNA during the photocycloaddition process.

Although J-aggregates are usually assumed to form in the minor groove of DNA, ${ }^{[3]}$ it is not possible at this time to unambiguously assert the exact nature of the groove binding mode of the aplysinopsin derivatives. Nevertheless, these results highlight the different roles played by both the leading (positively charged) and following (neutral) monomers during the aggregation process, which results in the [2+2] cycloaddition.

Hence, starting from three different natural aplysinopsin-derived monomers, we were able to access four cyclobutane-centered skeletons, including natural dictazole B. Interestingly, the homodimer $\mathbf{2 a}$ could also be further converted to yet another natural product, tubastrindole $\mathrm{B}$, through a ring-expansion cascade involving the formation of Mancini's intermediate (Scheme 1), thus showcasing the possible generalization of this approach to the entire aplysinopsin family of natural products. ${ }^{[34]}$ 


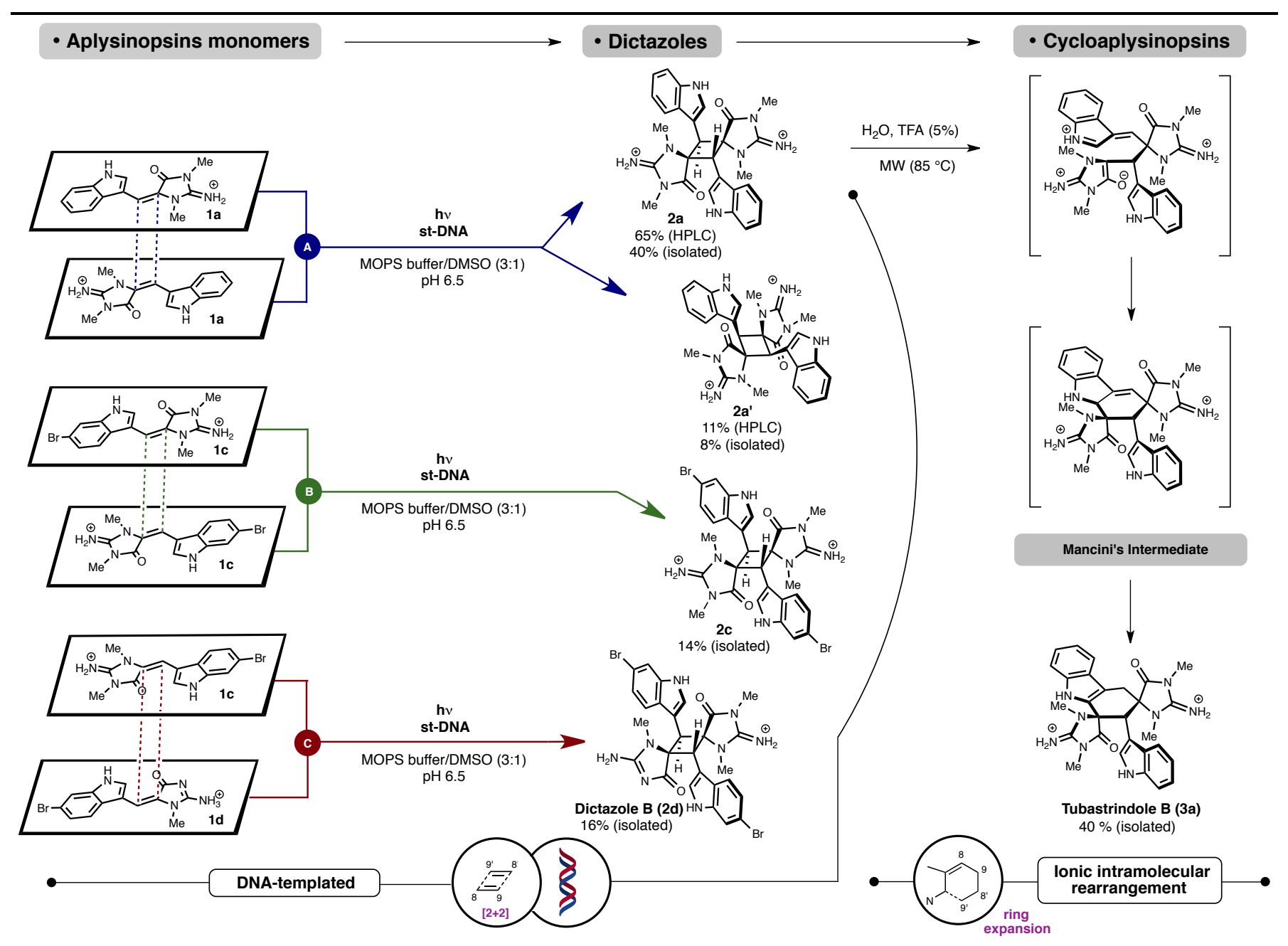

Scheme 1. Expanding the method to the aplysinospin series and cycloaplysinopsin counterparts after ring expansion

In summary, we've developed an unprecedented DNA-templated [2+2] photodimerization process and demonstrated its synthetic utility by applying it to the synthesis of spiro-fused cyclobutane-containing compounds including the natural heterodimer dictazole $\mathrm{B}$. The latter was obtained in $16 \%$ isolated yield, which significantly improved the results obtained under the standard solvent-free conditions. Moreover, by applying solid-state supramolecular principles ascertained by CD spectroscopy, we have shown that DNA could be a useful template to build aggregates with photoreactive units. Most importantly, we believe that this method is not limited to the aplysinopsins. Indeed, by fine-tuning the specific interaction between DNA and any given monomer, we should be able to extend the scope of the method and thus pave the way to new target-oriented syntheses.

\section{Acknowledgements}

The authors gratefully thank the Agence Nationale de la Recherche for financial support (D-CYSIV project; ANR-2015-CE29-0021-01).

Received: ((will be filled in by the editorial staff))

Published online on ((will be filled in by the editorial staff))

Keywords: DNA - [2+2] photocycloaddition - templated synthesis . synthesis - Aplysinopsin - Dictazole B

[1] a) N. Hoffmann, Chem. Rev. 2008, 108, 1052; b) S. Thompson; A. G. Coyne, P. C. Knipe, M. D. Smith, Chem.
Soc. Rev. 2011, 40, 4217; c) K. Glusac, Nat. Chem. 2016, 8, 734; d) T. Bach, J. P. Hehn, Angew. Chem. Int. Ed. 2011, 50, 1000 .

[2] a) T. P. Nicholls, D. Leonori, A. C. Bissember, Nat. Prod. Rep. 2016, 33, 1248; b) B. S. Matsuura, P. Kölle, D. Trauner, R. Vivie-Riedle, R. Meier, ACS Central Sci. 2017, 3, 39; c) D. Stichnoth, P. Kölle, T. J. Kimbrough, E. Riedle, R. Vivie-Riedle, D. Trauner, Nat. Commun. 2014, 6, 5597; d) T. Bach, J. P. Hehn, Angew. Chem. Int. Ed. 2011, 50, 1000; e) F. Mayr, C. Wiegand, T. Bach, Chem. Commun. 2014, 50, 3355; f) S. Poplata, A. Tröster, Y. Q. Zhou, T. Bach, Chem. Rev. 2016, 116, 9748.

[3] a) B. Bibal, C. Mongin, D. M. Bassani, Chem. Soc. Rev. 2014 43, 4179; b) J. Svoboda, B. Konig, Chem. Rev. 2006, 106, 5413.

[4] a) V. Ramamurthy, J. Sivaguru, Chem. Rev. 2016, 116, 9914; b) S. J. Barrow, S. Kasera, M. J. Rowland, J. del Barrio, O. A. Scherman, Chem. Rev. 2015, 115, 12320; c) K. I. Assaf, W. M. Nau, Chem. Soc. Rev. 2015, 44, 394; d) B. C. Pemberton, N. Barooah, D. K. Srivatsava, J. Sivaguru, Chem. Commun. 2010, 46, 225; e) A. T. Mansour, J. Buendia, J. Xie, F. Brisset, S. Robin, D. Naoufal, O. Yazbeck, D. J. Aitken, J. Org. Chem. 2017, 82, 9832 .

[5] G. Roelfes, B. L. Feringa, Angew. Chem. Int. Ed. 2005, 44, 3230 .

[6] a) N. Duchemin, I. Heath-Apostolopoulos, M. Smietana, S. Arseniyadis, Org. Biomol. Chem. 2017, 15, 7072; b) A. Rioz-Martínez, J. Oelerich, N. Ségaud, G. Roelfes, Angew. Chem. Int. Ed. 2016, 55, 14136; c) A. Rioz-Martinez, G. Roelfes, Curr. Opin. Chem. Biol. 2015, 25, 80; d) S. Park, H. Sugiyama, Molecules 2012, 17, 12792; e) A. J. Boersma, R. P. Megens, B. L. Feringa, G. Roelfes, Chem. Soc. Rev. 
2010, 39, 2083; f) S. Park, H. Sugiyama, Angew. Chem. Int Ed. 2010, 49, 3870; g) S. K. Silverman, Angew. Chem. Int. Ed. 2010, 49, 7180 .

[7] a) J. Wang, E. Benedetti, L. Bethge, S. Vonhoff, S Klussmann, J.-J. Vasseur, J. Cossy, M. Smietana, S. Arseniyadis, Angew. Chem. Int. Ed. 2013, 52, 11546; b) E. Benedetti, N. Duchemin, L. Bethge, S. Vonhoff, S. Klussmann, J.-J. Vasseur, J. Cossy, M. Smietana, S. Arseniyadis, Chem. Commun. 2015, 51, 6076; c) K. Amirbekyan, N. Duchemin, E. Benedetti, R. Joseph, A. Colon, S. A. Markarian, L. Bethge, S. Vonhoff, S. Klussmann, J. Cossy, J.-J. Vasseur, S. Arseniyadis, M. Smietana, ACS Catal. 2016, 6, 3096; d) N. Duchemin, E. Benedetti, L. Bethge, S. Vonhoff, S. Klussmann, J.-J. Vasseur, J. Cossy, M. Smietana, S. Arseniyadis, Chem. Commun. 2016, 52, 8604 .

[8] a) N. Gaß, J. Gebhard, H.-A. Wagenknecht, ChemPhotoChem 2017, 1, 48; b) U. Reisacher, L. Antusch, R. Hofsäß, C. Schwechheimer, B. Lehmann, H.-A. Wagenknecht, Curr. Opin. Chem. Biol. 2017, 40, 119.

[9] A. Skiredj, M. A. Beniddir, D. Joseph, K. Leblanc, G. Bernadat, L. Evanno, E. Poupon, Angew. Chem. Int. Ed. 2014, 53, 6419 .

[10] A. Garcia-Fernández, R. P. Megens, L. Villarino, G. Roelfes, J. Am. Chem. Soc. 2016, 138, 16308 .

[11] The use of DMSO was shown not to perturb the double-helix structure of DNA, see: a) J. F. Escara, J. R. Hutton, Biopolymers, 1980, 19, 1315-1327; b) S. A. Markarian, A. M. Asatryan, K. R. Grigoryan, H. R. Sargsyan Biopolymers, 2006, $82,1-5$ and references therein.

[12] Reaction run on a $0.15 \mathrm{mmol}$ scale in a crystallizer dish with slow magnetic stirring and direct irradiation.

[13] A similar yield could be obtained using a $1.3 \mathrm{mM}$ base pair concentration of st-DNA after $24 \mathrm{~h}$.

[14] M. Misiak, F. Mantegazza, G. L. Beretta, Curr. Pharm. Des. 2016, 22, 6596

[15] a) N. C. Garbett, P. A. Ragazzon, J. B. Chaires, Nature Protocols, 2007, 2, 3166; b) B. Nordén, T. Kurucsev, J. Mol. Recognit., 1994, 7, 141; c) Y. Y. Mao, K. Y. Liu, L. Chen, X. H. Cao, T. Yi, Chem. Eur. J. 2015, 21, 16623.

[16] W. C. Tse, D. L. Boger, Acc. Chem. Res. 2004, 37, 61.

[17] a) A. L. Stadler, B. R. Renikuntla, D. Yaron, A. S. Fang, B. A. Armitage, Langmuir 2011, 27, 1472; b) B. A. Armitage, in DNA Binders, Related Subjects, Eds. M. J. Waring, J. B. Chaires, 2005, vol. 253, pp. 55; c) K. C. Hannah, B. A. Armitage, Acc. Chem. Res. 2004, 37, 845 .

[18] a) K. A. Schug, W. Lindner, Chem. Rev. 2005, 105, 67; b) K. Ohara, M. Smietana, J.-J. Vasseur, J. Am. Soc. Mass Spectrom. 2006, 17, 283; c) K. Amirbekyan, J. Mansot, K. Ohara, S. A. Markarian, J.-J. Vasseur, M. Smietana, Tetrahedron Lett. 2018, 59, 293.

[19] M. Wang, G. L. Silva, B. A. Armitage, J. Am. Chem. Soc. 2000, 122,9977

[20] L. Di Bari, G. Pescitelli, P. Salvadori, J. Am. Chem. Soc. 1999 121, 7998.

[21] B. L. Cannon, D. L. Kellis, L. K. Patten, P. H. Davis, J. Lee, E. Graugnard, B. Yurke, W. B. Knowlton, J. Phys. Chem. A 2017, 121, 6905.

[22] T. Šmidlehner, I. Piantanida, G. Pescitelli, Beilstein J. Org. Chem. 2018, 14, 84.

[23] S. M. Nelson, L. R. Ferguson, W. A. Denny, Mutat. Res. 2007, $623,24$.

[24] S. Nishizawa, Y. Kato, N. Teramae, J. Am. Chem. Soc. 1999 , $121,9463$.

[25] a) E. M. Boyd, J. J. Sperry, Chem. N. Z. 2010, 74, 109; b) J. Dai, J.; Jimenez, J. I.; Kelly, M.; Williams, P. G. J. Org. Chem. 2010, 75, 2399.

[26] R. Kazlauskas, P. T. Murphy, R. J. Quinn, R. J. Wells, Tetrahedron Lett. 1977, 18, 61

[27] A. Skiredj, M. A. Beniddir, D. Joseph, G. Bernadat, L. Evanno, E. Poupon, Synthesis 2015, 47, 2367.
[28] a) I. Mancini, G. Guella, H. Zibrowius, F. Pietra, Tetrahedron 2003, 59, 8757; b) M. Meyer, F. Delberghe, F. Liron, M. Guillaume, A. Valentin, M. Guyot, Nat. Prod. Res. 2009, 23, 178.

[29] a) T. Isagawa, M. Miyazaki, H. Okamura, M. Nakatani, M. Doe, K. Takemura, Tetrahedron Lett. 2003, 44, 2533; b) T. Isagawa, M. Miyazaki, Y. Yokogawa, H. Okamura, M. Nakatani, M. Doe, Y. Morimoto, K. Takemura, Heterocycles 2008, 75, 2023; c) W. Balansa, R. Islam, D. F. Gilbert, F. Fontaine, X. Xiao, H. Zhang, A. M. Piggott, J. W. Lynch, R. J. Capon, Bioorg. Med. Chem. 2013, 21, 4420.

[30] J. Dai, J. I. Jimenez, M. Kelly, S. Barnes, P. Lorenzo, P. G. Williams, J. Nat. Prod. 2008, 71, 1287.

[31] A. Skiredj, M. A. Beniddir, D. Jospeh, K. Leblanc, G. Bernadat, L. Evanno, E. Poupon. Org. Lett. 2014, 16, 4980.

[32] Under these conditions, we were also able to isolate $4 \%$ of $\mathbf{2 c}$ resulting from the homodimerization of $\mathbf{1 c}$

[33] Losytskyy, M. Y.; Yashchuk, V. M.; Fluorescent J-Aggregates and their Biological Applications in Advanced Fluorescence Reporters in Chemistry and Biology II. Springer Series on Fluorescence (Methods and Applications), Ed. A. Demchenko, vol 9. Springer, Berlin, Heidelberg (2010).

[34] M. A. Beniddir, L. Evanno, D. Jospeh, A. Skiredj, E. Poupon, Nat. Prod. Rep. 2016, 33, 820. 
